\title{
Renal Cell Tumors: Understanding Their Molecular Pathological Epidemiology and the 2016 WHO Classification
}

\author{
Kentaro Inamura \\ Division of Pathology, The Cancer Institute, Japanese Foundation for Cancer Research, 3-8-31 Ariake, Koto-ku, \\ Tokyo 135-8550, Japan; kentaro.inamura@jfcr.or.jp; Tel.: +81-3-3570-0111 (ext. 5604); Fax: +81-3-3570-0558
}

Received: 22 August 2017; Accepted: 17 October 2017; Published: 20 October 2017

\begin{abstract}
Accumulating evidence suggests that renal cell tumors represent a group of histologically and molecularly heterogeneous diseases, even within the same histological subtype. In accordance with the increased understanding of the morphological, immunohistochemical, molecular, and epidemiological characteristics of renal cell tumors, the World Health Organization (WHO) classification of renal cell tumors has been modified. This review provides perspectives on both new and current subtypes of renal cell tumors, as well as on the emerging/provisional renal cell carcinomas in the new 2016 WHO classification, which focuses on features of their molecular pathological epidemiology. The WHO classification will require additional revisions to enable the classification of renal cell tumors as clinically meaningful subtypes and provide a better understanding of the unique characteristics of renal cell tumors.
\end{abstract}

Keywords: histology; immunohistochemistry; kidney; genetic alteration; molecular pathology; renal cell carcinoma

\section{Introduction}

Renal cell tumors represent a group of histopathologically and molecularly heterogeneous tumors, with different sets of genetic and epigenetic abnormalities [1-27]. An increased understanding of the morphology, immunohistochemistry, genomics, and epidemiology of renal cell tumors has resulted in the identification of novel features in their molecular pathological epidemiology. On the basis of these features, the classification of renal cell tumors has recently been revised and published in the 2016 World Health Organization (WHO) classification [1]. The revisions reflect the increased understanding of the characteristic features of renal cell tumors. This review introduces and briefly summarizes the molecular pathological epidemiologic features of both new and current subtypes of renal cell tumors, as well as of emerging/provisional renal cell carcinomas (RCCs), in the 2016 WHO classification.

\section{The 2016 WHO Classification}

The revised WHO classification is based on advances in the understanding of newly identified characteristics of the molecular pathological epidemiology of renal cell tumors. The majority of the International Society of Urological Pathology (ISUP) Vancouver classification of renal neoplasia [28] was adopted for the revised 2016 WHO classification of renal cell tumors [1]. Perspectives on both new and current subtypes of renal cell tumors, as well as on emerging/provisional RCCs in the new 2016 WHO classification, are described below.

The various subtypes of renal cell tumors are based on descriptive or characteristic features (Table 1) [1]. The major subtypes are clear cell RCC (CCRCC) (Figure 1A), papillary RCC (PRCC) (Figure 1B), and chromophobe RCC (ChRCC) (Figure 1C), which comprise 65-70\%, 15-20\%, and 5-7\% of all RCCs, respectively. The names of these subtypes are based on their predominant cytoplasmic 
(cellular) and staining features (e.g., CCRCC, ChRCC, and renal oncocytoma), structural and morphological features (e.g., PRCC), and combinations of these features (e.g., clear cell papillary RCC (CCPRCC)). Other terms for renal cell tumors are based on the anatomical location of the tumor (e.g., collecting duct and renal medullary carcinomas), association with renal disease (e.g., acquired cystic disease-associated RCC (ACD-associated RCC)), pathognomonic molecular alterations (e.g., microphthalmia transcription factor (MiT) family translocation RCC (TRCC) and succinate dehydrogenase-deficient RCC (SDH-deficient RCC)), and familial predisposition (e.g., hereditary leiomyomatosis and RCC-associated RCC (HLRCC-associated RCC)) [1].

Table 1. Classification of renal cell tumors according to the 2016 WHO classification [1].

\begin{tabular}{ll}
\hline \multicolumn{1}{c}{ Current Renal Cell Tumor Subtypes } & \multicolumn{1}{c}{ New Renal Cell Tumor Subtypes } \\
\hline Clear cell RCC & Multilocular cystic renal neoplasm of low malignant potential \\
Papillary RCC & MiT family translocation RCC \\
Chromophobe RCC & Tubulocystic RCC \\
Collecting duct carcinoma & Acquired cystic disease-associated RCC \\
Renal medullary carcinoma & Clear cell papillary RCC \\
Mucinous tubular and spindle cell carcinoma & Succinate dehydrogenase-deficient RCC \\
RCC, unclassified & Hereditary leiomyomatosis and RCC-associated RCC \\
Papillary adenoma & \\
Oncocytoma & \\
\hline
\end{tabular}

MiT, microphthalmia transcription factor; RCC, renal cell carcinoma; WHO, World Health Organization.

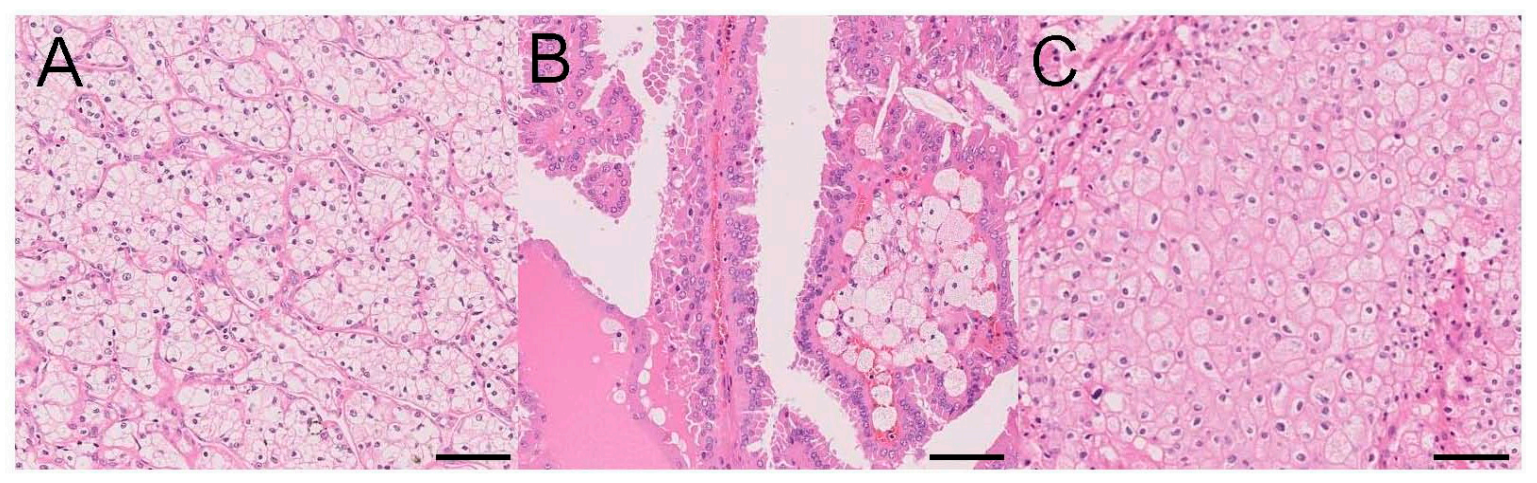

Figure 1. Morphology of the major subtypes of renal cell carcinoma (RCC) (hematoxylin and eosin staining; scale bar, $100 \mu \mathrm{m}$ ). (A) Clear cell RCC; (B) papillary RCC; and (C) chromophobe RCC. Clear cell RCC typically consists of clear cells with thin-walled, staghorn-shaped vasculature (A). Papillary RCC is typically composed of papillae formed by fibrovascular cores that often contain foamy macrophages (B). Chromophobe RCC typically contains a mixture of eosinophilic and clear cells with voluminous cytoplasm, perinuclear clearance, and well-defined cell borders, displaying a solid, sheet-like pattern $(\mathbf{C})$.

\section{Current Major Subtypes}

In this section, the current major subtypes of renal cell tumors in the 2016 WHO classification are briefly summarized, with a focus on their molecular pathological epidemiology. Their characteristic features are summarized in Table 2. 
Table 2. Current major subtypes of renal cell tumors in the 2016 WHO classification [1].

\begin{tabular}{|c|c|c|c|}
\hline $\begin{array}{l}\text { Renal Cell Tumor } \\
\text { Subtypes }\end{array}$ & Clinical Features & $\begin{array}{l}\text { Morphological/Immunohistochemical } \\
\text { Features }\end{array}$ & Molecular Features \\
\hline CCRCC & $65-70 \%$ of adult RCCs & $\begin{array}{l}\text { Clear/eosinophilic cells with } \\
\text { thin-walled, staghorn-shaped } \\
\text { vasculature; positive for CAIX and } \\
\text { CD10, negative for CK7 and AMACR }\end{array}$ & $\begin{array}{l}\text { Loss of function of } V H L, C h r 3 p \text { deletion, } \\
\text { inappropriate stabilization of HIFs, genetic } \\
\text { mutations in PI3K/AKT pathway, } \\
\text { mutations of SETD2, BAP1, and MTOR, } \\
\text { aggressive CCRCC demonstrating } \\
\text { a metabolic shift }\end{array}$ \\
\hline PRCC & $\begin{array}{l}15-20 \% \text { of adult RCCs, } \\
\text { type } 1 \text { shows a better } \\
\text { prognosis than type } 2\end{array}$ & $\begin{array}{l}\text { Papillary structure, foamy } \\
\text { macrophages; } \\
\text { type 1: scanty cytoplasm; } \\
\text { type 2: abundant eosinophilic } \\
\text { cytoplasm; positive for CD10, CK7, } \\
\text { and AMACR, negative for CAIX }\end{array}$ & $\begin{array}{l}\text { Gain of Chr } 7 \text { and/or Chr 17, loss of Chr Y; } \\
\text { type 1: MET alteration; } \\
\text { type 2: CDKN2A silencing, } \\
\text { SETD2 mutation; } \\
\text { three subtypes according to the TCGA, } \\
\text { including CIMP-associated aggressive } \\
\text { subtype with an } F H \text { mutation }\end{array}$ \\
\hline ChRCC & $\begin{array}{l}5-7 \% \text { of adult RCCs, } \\
\text { favorable prognosis, } \\
\text { Birt-Hogg-Dube } \\
\text { syndrome with } \\
\text { an FLCN mutation }\end{array}$ & $\begin{array}{l}\text { Prominent cell membrane, irregular } \\
\text { nuclei, perinuclear halo, pale to } \\
\text { eosinophilic cytoplasm; positive for } \\
\text { KIT and CK7, negative for CAIX } \\
\text { and CD10 }\end{array}$ & $\begin{array}{l}\text { Loss of Chrs } 1,2,6,10,13 \text {, and } 17 \text {, somatic } \\
\text { mutation in mitochondrial DNA, } \\
\text { mutations of TP53 and PTEN, imbalanced } \\
\text { chromosome duplication (ICD), high TERT } \\
\text { expression by DNA rearrangement within } \\
\text { the TERT promoter region with kataegis }\end{array}$ \\
\hline
\end{tabular}

CCRCC, clear cell RCC; Chr, chromosome; ChRCC, chromophobe RCC; CIMP, CpG island methylator phenotype; HIF, hypoxia-inducible factor; PRCC, papillary RCC; RCC, renal cell carcinoma; TCGA, The Cancer Genome Atlas; VHL, von Hippel Lindau; WHO, World Health Organization.

\subsection{Clear Cell RCC (CCRCC)}

CCRCCs comprise $65-70 \%$ of all adult RCCs. Macroscopically, CCRCCs appear typically yellow, with evidence of necrosis and hemorrhage. Microscopically, CCRCCs consist of clear/eosinophilic cells with thin-walled, staghorn-shaped vasculature. The cytoplasm of CCRCCs is typically clear from an abundant accumulation of glycogen and lipids. Immunohistochemically, CCRCCs are typically positive for CAIX and CD10, and negative for CK7 and AMACR. Genetically, a loss of function of $V H L$ at 3p25-26 is nearly ubiquitous. One copy of $V H L$ is either mutated or silenced in $90 \%$ of sporadic CCRCCs, whereas another copy is typically lost through $3 p$ deletions, according to the comprehensive molecular profiling of CCRCCs by The Cancer Genome Atlas (TCGA) [2]. The biallelic loss of VHL allows for the inappropriate stabilization of hypoxia-inducible factors (HIFs), which results in a proangiogenic gene expression signature that is critical to the carcinogenesis of CCRCC $[29,30]$. According to the TCGA, CCRCCs are characterized by recurrent mutations in the PI3K/AKT/MTOR pathway (a potential therapeutic target), mutations in SETD2 (associated with widespread DNA hypomethylation), and mutations involving the SWI/SNF chromatin remodeling complex (PBRM1, ARID1A, and SMARCA4). Aggressive CCRCCs demonstrate a metabolic shift [2].

\subsection{Papillary RCC (PRCC)}

PRCC comprise $15-20 \%$ of all adult RCCs. PRCCs have been associated with a better prognosis than CCRCCs. Furthermore, type 1 PRCCs are associated with a better prognosis than type 2 PRCCs. However, recent evidence suggests that metastatic PRCC patients fare worse than metastatic CCRCC patients [31]. Hereditary PRCC syndrome with germline mutations in MET is associated with type 1 PRCCs. Macroscopically, these tumors usually display a friable appearance with evidence of necrosis and hemorrhage. Microscopically, PRCCs have been traditionally subclassified into two subtypes. Type 1 PRCCs have papillae, covered by cells with scanty cytoplasm and nuclei, arranged in a single layer on the papillary cores, with or without foamy macrophages. Type 2 PRCCs are typically composed of cells with abundant eosinophilic cytoplasm and large pseudostratified nuclei that line papillary structures with true fibrovascular cores, with or without foamy macrophages. A subset of PRCCs has a mixed histology. Immunohistochemically, PRCCs are typically positive for CD10, CK7, and AMACR, and negative for CAIX. Of note, CK7 positivity is more prominent in type 1 PRCCs and is often decreased in type 2 PRCCs. Therefore, CK7 positivity may not be entirely helpful in distinguishing PRCCs from 
ACD-associated RCCs and HLRCC-associated RCCs, both of which are usually composed of cells with eosinophilic cytoplasm, frequently showing a papillary/tubular pattern. Genetically, gain of chromosomes 7 and/or 17 and loss of the Y chromosome are characteristically associated with PRCCs. According to the comprehensive molecular profiling of PRCCs by TCGA [3], type 1 PRCCs are characterized by MET alterations, whereas type 2 PRCCs are characterized by CDKN2A silencing, SETD2 mutations, and increased expression of the NRF2-antioxidant response element pathway. Using multiplatform analyses, type 2 PRCCs have been categorized into three clusters (C2a, C2b, and C2c). C2c PRCCs are $\mathrm{CpG}$ island methylator phenotype (CIMP)-associated tumors, characterized by poor survival and $F H$ mutations. C2a PRCCs are associated with early stages of tumor development. C2b PRCCs are associated with later stages of tumor development and SETD2 mutations [3].

\subsection{Chromophobe RCC (ChRCC)}

ChRCCs, comprising $5-7 \%$ of all adult RCCs, have a favorable prognosis. Birt-Hogg-Dube syndrome with FLCN mutations is associated with a higher incidence of ChRCCs. Macroscopically, the cut surfaces of ChRCCs appear light tan, to brown, to mahogany-brown. Microscopically, ChRCCs are characterized by cells with prominent cell membranes, irregular nuclei with perinuclear halos, and pale to eosinophilic cytoplasm. The eosinophilic variant of ChRCCs shows predominantly smaller eosinophilic granular cells with irregular nuclei and perinuclear halos [1]. Immunohistochemically, ChRCCs are typically positive for KIT and CK7, and negative for CAIX and CD10. Genetically, ChRCCs show losses of chromosomes 1, 2, 6, 10,13, and 17. Eosinophilic variants may have fewer genetic losses [4]. Somatic mutations in mitochondrial DNA are common. TP53 and PTEN are frequently mutated, in $32 \%$ and $9 \%$ of ChRCCs, respectively [4]. Recurrent DNA rearrangement breakpoints within the TERT promoter region in $10 \%$ of examined cases of ChRCCs, which are associated with high TERT expression and manifestation of kataegis, represent a mechanism for increased TERT expression in these tumors, differing from the point mutations of TERT observed in various malignancies [4]. A recent study has demonstrated that metastatic ChRCCs were characterized by TP53 mutations (58\%), PTEN mutations (24\%), and imbalanced chromosome duplication (ICD) (25\%), suggesting these genomic changes are involved in metastatic evolution for ChRCCs [24].

\section{New Subtypes}

In the 2016 WHO classification, seven new subtypes were adopted, as shown in Table 1. The features of their molecular pathological epidemiology are briefly summarized in Table 3.

Table 3. New subtypes of renal cell tumors in the 2016 WHO classification [1].

\begin{tabular}{|c|c|c|c|}
\hline $\begin{array}{l}\text { New Renal Cell Tumor } \\
\text { Subtypes }\end{array}$ & Clinical Features & $\begin{array}{c}\text { Morphological/Immunohistochemical } \\
\text { Features }\end{array}$ & Molecular Features \\
\hline $\begin{array}{l}\text { Multilocular cystic renal } \\
\text { neoplasm of low } \\
\text { malignant potential }\end{array}$ & Excellent prognosis & $\begin{array}{l}\text { Numerous cysts lined by clear cells; positive for } \\
\text { CAIX and CK7 }\end{array}$ & $\begin{array}{l}\text { VHL mutation, } \\
\text { Chr 3p deletion }\end{array}$ \\
\hline MiT family TRCC & $\begin{array}{l}\text { Pediatric to young adult } \\
\text { patients, mean age of } \\
30 \text { years }\end{array}$ & $\begin{array}{l}\text { Papillary pattern, psammoma bodies, large } \\
\text { epithelioid cells and small cells; positive for } \\
\text { TFE3 or TFEB }\end{array}$ & $\begin{array}{l}\text { Xp11 TRCC: TFE3 } \\
\text { rearrangement, } \mathrm{t}(6 ; 12) \\
\text { RCC: TFEB } \\
\text { rearrangement }\end{array}$ \\
\hline Tubulocystic RCC & $\begin{array}{l}\text { Male predominance, mean } \\
\text { age of } 60 \text { years, indolent }\end{array}$ & Dilated tubules with a single layer of cells & $\begin{array}{l}\text { Gain of Chrs } 7 \text { and 17, } \\
\text { loss of Chr Y }\end{array}$ \\
\hline ACD-associated RCC & $\begin{array}{l}\text { End-stage renal disease or } \\
\mathrm{ACD} \text {, indolent }\end{array}$ & $\begin{array}{l}\text { Eosinophilic cytoplasm, sieve-like pattern, } \\
\text { intratumoral oxalate crystals; positive for } \\
\text { AMACR and CD10, negative for CK7 }\end{array}$ & Gain of Chrs 3, 16, and $Y$ \\
\hline CCPRCC & $\begin{array}{l}\text { 3-4\% of renal tumors, } \\
\text { indolent, end-stage renal } \\
\text { disease, VHL disease }\end{array}$ & $\begin{array}{l}\text { Clear cytoplasm, papillary pattern, } \\
\text { apical-oriented nuclei; positive for CK7 and } \\
\text { CAIX, negative for CD10 }\end{array}$ & $\begin{array}{l}\text { Lack of the genomic } \\
\text { alterations observed in } \\
\text { CCRCC/PRCC }\end{array}$ \\
\hline
\end{tabular}


Table 3. Cont.

\begin{tabular}{|c|c|c|c|}
\hline $\begin{array}{l}\text { New Renal Cell Tumor } \\
\text { Subtypes }\end{array}$ & Clinical Features & $\begin{array}{l}\text { Morphological/Immunohistochemical } \\
\text { Features }\end{array}$ & Molecular Features \\
\hline SDH-deficient RCC & $\begin{array}{l}0.05-0.2 \% \text { of renal } \\
\text { carcinomas, mean age of } 37 \\
\text { years, good prognosis, } \\
\text { germline mutation in one of } \\
\text { the } S D H \text { genes }\end{array}$ & $\begin{array}{l}\text { Cytoplasmic vacuoles and inclusion-like spaces; } \\
\text { negative for SDHB, KIT, and CK7 }\end{array}$ & $\begin{array}{l}\text { Double-hit inactivation } \\
\text { of one of the SDH genes, } \\
\text { most commonly SDHB, } \\
\text { no mutations in VHL, } \\
P I K 3 C A, A K T, M T O R, \\
M E T \text {, or TP53 }\end{array}$ \\
\hline HLRCC-associated RCC & $\begin{array}{l}\text { HLRCC syndrome, } \\
\text { aggressive }\end{array}$ & $\begin{array}{l}\text { Large nuclei with inclusion-like eosinophilic } \\
\text { nucleoli and perinuclear clearing, abundant } \\
\text { eosinophilic cytoplasm, papillary/tubular } \\
\text { pattern; positive for S-(2-succino)-cysteine (2SC), } \\
\text { negative for FH, CK19, 34betaE12, and CK7 }\end{array}$ & $\begin{array}{l}\text { Germline mutation in } \\
\text { FH, metabolic shift to } \\
\text { aerobic glycolysis, } \\
\text { increased fumarate and } \\
\text { HIF1A }\end{array}$ \\
\hline
\end{tabular}

ACD, acquired cystic disease; CCPRCC, clear cell papillary RCC; CCRCC, clear cell RCC; Chr, chromosome; HLRCC, Hereditary leiomyomatosis and RCC; MiT, microphthalmia transcription factor; PRCC, papillary RCC; RCC, renal cell carcinoma; SDH, succinate dehydrogenase, TRCC, translocation RCC; VHL, von Hippel Lindau; WHO, World Health Organization.

\subsection{Multilocular Cystic Renal Neoplasm of Low Malignant Potential}

According to the 2004 WHO classification [32], multilocular cystic RCC exhibits an excellent prognosis; therefore, its name was changed to multilocular cystic renal neoplasm of low malignant potential. It is defined as a renal tumor composed entirely of cysts, the septa of which contain individual, or groups of, clear cells without expansive growth [1]. Immunohistochemically, the neoplastic cells are positive for CAIX and CK7, as is the case for CCPRCC [33]. As genetic studies have distinctly linked multilocular cystic RCC with CCRCC [33,34], multilocular cystic renal neoplasm of low malignant potential is similar to CCRCC, not only morphologically but also genetically. Similar to CCRCC, chromosome $3 p$ deletions and VHL mutations were found in $74 \%$ and $25 \%$ of these tumors, respectively $[34,35]$.

\subsection{MiT Family Translocation RCC (MiT Family TRCC)}

Xp11 TRCC was established as an RCC subtype in the 2004 WHO classification [32]. In the 2016 WHO classification [1], MiT family TRCC, composed of Xp11 TRCC and $t(6 ; 11)$ RCC, was newly defined as an RCC subtype. Both Xp11 translocation and $t(6 ; 11)$ RCC are characterized by the rearrangement of the MiT transcription factors, TFE3 and TFEB [36]. Xp11 TRCC comprises $20-40 \%$ of pediatric RCCs and $1-4 \%$ of adult RCCs, with an average age of onset of 50 years $[37,38]$. The $t(6 ; 11)$ RCC subtype is very rare, with approximately 60 cases reported to date. The mean and median patient ages are both approximately 30 years [39]. Morphologically, Xp11 TRCC is typically composed of cells with clear/eosinophilic cytoplasm with papillary and nested structures and psammoma bodies. The tumor cells are large with prominent nucleoli $[40,41]$. The $t(6 ; 11)$ RCC subtype typically shows a biphasic component and is composed of nests of larger epithelioid cells and smaller cells around the basement membrane [42,43]. However, MiT family TRCCs occasionally show diverse morphological patterns without a characteristic morphology [44,45]. Specifically, Xp11 TRCC and $t(6 ; 11)$ RCC display positive nuclear immunostaining for TFE3 and TFEB, respectively [45,46]. Xp11/TFEB TRCC is diagnosed by the utilization of TFE3/TFEB immunohistochemistry or break-apart TFE3/TFEB fluorescence in in situ hybridization in formalin-fixed paraffin-embedded (FFPE) specimens [43,45-48]. A recent study suggested that the reverse transcriptase-polymerase chain reaction is a highly sensitive and specific method that can be used with FFPE tissues for the diagnosis of Xp11 TRCC [49]. Another recent study demonstrated that TFEB-amplified RCCs with or without TFEB translocation were characterized by aggressive clinical behavior, variable morphology, aberrant melanocytic marker expression, and high frequency of immunohistochemical positivity for TFEB [50]. 


\subsection{Tubulocystic RCC}

Tubulocystic RCC is an uncommon cystic RCC, comprising fewer than $1 \%$ of all RCCs. Patients have a mean age of 60 years and are predominantly male [51-54]. Morphologically, tubulocystic RCC is composed of small- to intermediate-sized tubules and cystically dilated larger tubules. The luminal spaces are lined by a single layer of atypical cells with a cuboidal/hobnail configuration. The tumor cells have enlarged nuclei with prominent nucleoli and abundant eosinophilic cytoplasm [1,28]. Immunohistochemically, the tumor is positive for CD10 and AMACR [28]. Tubulocystic RCC shows gains of chromosomes 7 and 17, and loss of the Y chromosome, suggesting similarity with PRCC. Although collecting duct carcinoma occasionally displays areas that morphologically resemble tubulocystic RCC [55], gene expression profiling studies suggest that tubulocystic RCC and collecting duct carcinoma should be considered two distinct entities at the molecular level [56]. Recent evidence has shown that tubulocystic RCC with poorly differentiated foci is strongly associated with an FH-deficient status and aggressive behavior [57].

\subsection{Acquired Cystic Disease-Associated RCC (ACD-Associated RCC)}

ACD-associated RCC is the most common tumor of the kidney in patients with end-stage renal disease and ACD [1,58]. ACD-associated RCC is generally indolent; however, a subset of patients with ACD-associated RCC may suffer from metastatic disease [28,59]. Microscopically, ACD-associated RCC is characterized by tumor cells with eosinophilic cytoplasm, cribriform/sieve-like patterns, and intratumoral oxalate crystals. ACD-associated RCC has variable structures, including papillary, tubulocystic, macrocystic, solid, and cribriform patterns $[28,58,60]$. The presence of intratumoral oxalate crystals and intracytoplasmic microlumen formation (vacuoles) imparting a cribriform, microcystic, sieve-like pattern, helps distinguish ACD-associated RCC from other renal neoplasms. The tumor cells are typically large with eosinophilic granular cytoplasm, ill-defined cell membranes, and prominent nucleoli $[1,28,58]$. Immunohistochemically, ACD-associated RCC is typically positive for AMACR and CD10, and negative for CK7 [1]. Genetically, the high prevalence of gains of chromosomes 3, 16, and Y can distinguish ACD-associated RCC from PRCC, with which ACD-associated RCC shows overlapping morphological and immunophenotypic features.

\subsection{Clear Cell Papillary RCC (CCPRCC)}

CCPRCC is likely the fourth most common RCC subtype, accounting for approximately $3-4 \%$ of all renal tumors, close in incidence to that of ChRCC [61,62]. CCPRCC is generally indolent, with very rare reports of recurrence or metastasis [61-64]. CCPRCC is composed of cells with clear cytoplasm and often shows a papillary structure; however, it demonstrates tubular, papillary, and solid patterns of varying proportions $[61,63,64]$. One of its characteristic morphologies is the presence of apicalto mid-oriented, linearly arranged uniform nuclei. Although this morphology may overlap with low-grade CCRCC/PRCC, the immunohistochemical characteristics of CCPRCC can help distinguish it from low-grade CCRCC/PRCC. CCPRCC is typically positive for CAIX and CK7, and negative for CD10 [61,63,64]. It generally lacks the genomic alterations observed in CCRCC/PRCC; It lacks the 3p deletion, VHL mutation, VHL promoter hypermethylation, and gain of chromosome 7 or 17 [63,65]. A study examining seven cases of CCPRCC, by comparative genomic hybridization, detected no chromosomal imbalances [66].

\subsection{Succinate Dehydrogenase-Deficient RCC (SDH-Deficient RCC)}

SDH-deficient RCC occurs predominantly in patients with germline mutations in one of the SDH genes: $S D H A, S D H B$ (most common), SDHC, or SDHD. Autosomal SDH genes encode proteins that assemble at the inner mitochondrial membrane to form mitochondrial complex 2 [67]. SDH-deficient RCC comprises $0.05-0.2 \%$ of all renal carcinomas, with a mean patient age of 37 years [68]. Metastasis from SDH-deficient RCC is rare [68,69]. Macroscopically, SDH-deficient RCC is usually 
well circumscribed with a tan to red cut surface [68]. Microscopically, SDH-deficient RCC is either well circumscribed or shows coarse lobulation with cystic changes in the form of microcysts and macrocysts, containing pale eosinophilic fluid. The most distinctive feature of these tumors is the presence of cytoplasmic vacuoles and inclusion-like spaces [68]. Immunohistochemically, SDH-deficient RCC is typically negative for SDHB, which is considered diagnostic for these tumors [1]. SDH-deficient RCC is also typically negative for KIT and CK7, which are usually present in ChRCC and can be used to distinguish SDH-deficient RCC from ChRCC. Genetically, the defining molecular abnormality in SDH-deficient RCC is the double-hit inactivation of one of the $S D H$ genes, most commonly SDHB $[1,68]$. A study examining six cases of SDH-deficient RCC by next-generation DNA sequencing showed that none of the examined cases harbored genetic mutations that contribute to RCC pathogenesis, including VHL, PIK3CA, AKT, MTOR, MET, and TP53 [70]. A recent study demonstrated that metastatic lethal SDHB-deficient RCCs characteristically exhibit diverse morphologies, including high-grade features, and show an extreme Warburg effect [71].

\subsection{Hereditary Leiomyomatosis and RCC-Associated RCC (HLRCC-Associated RCC)}

HLRCC-associated RCC occurs in patients with HLRCC syndrome, which is an autosomal dominant hereditary disease that is associated with germline mutations in $F H$ at chromosome 1q42.3-q43. The characteristic features of this syndrome are multiple cutaneous and uterine leiomyomas and HLRCC-associated RCCs. A diagnosis of HLRCC-associated RCC is confirmed by the presence of germline $F H$ mutations. In contrast to other syndrome-associated RCCs, HLRCC-associated RCC often occurs as a solitary mass with aggressive behavior. Thus, the prognosis of HLRCC-associated RCC is poor, with a tendency for early widespread dissemination [1,72]. Microscopically, HLRCC-associated RCC resembles type 2 PRCC and collecting duct carcinoma, is composed of tumor cells with an abundant eosinophilic cytoplasm, and shows a papillary/tubular pattern. The most distinctive feature of HLRCC-associated RCC is the presence of characteristically large nuclei with inclusion-like eosinophilic nucleoli and perinuclear clearing [63,73] Immunohistochemically, HLRCC-associated RCC is typically negative for high-molecular weight cytokeratins (CK19 and 34betaE12) and CK7, which are positive in collecting duct carcinoma, and can be included in a differential diagnosis with HLRCC-associated RCC. HLRCC-associated RCC is typically negative for CK7, which differs from PRCC, and CD10, except in areas with clear cell features [63,73]. Recently, immunohistochemistry to detect FH and S-(2-succino)-cysteine (2SC), whose accumulation is caused by a loss of FH enzymatic activity, has been developed [74]. HLRCC-associated RCC is characterized by negative immunohistochemical results for $\mathrm{FH}$ and positive results for 2SC [75]. Genetically, HLRCC-associated RCC is characterized by a germline mutation in FH. In HLRCC-associated RCCs, oxidative phosphorylation is impaired; therefore, tumor cells demonstrate a metabolic shift to aerobic glycolysis. In conditions of $F H$ deficiency, fumarate increases and becomes an oncometabolite. Increased fumarate impairs HIF prolyl hydroxylase, which results in increased HIF1A levels [1].

\section{Emerging/Provisional Entities}

The 2016 WHO classification identified emerging/provisional new entities that are rare and yet fully characterized by morphology, immunohistochemistry, and molecular analyses, and require refinement of their diagnostic criteria and the revealing of clinicopathological features [1]. The characteristic features of emerging/provisional entities are summarized in Table 4. 
Table 4. Emerging/provisional entities of RCCs in the 2016 WHO classification [1].

\begin{tabular}{|c|c|c|c|}
\hline $\begin{array}{l}\text { Emerging/Provisional } \\
\text { RCC Subtypes }\end{array}$ & Clinical Features & Morphological/Immunohistochemical Features & Molecular Features \\
\hline $\begin{array}{l}\text { Oncocytic RCC } \\
\text { occurring after } \\
\text { neuroblastoma }\end{array}$ & $\begin{array}{l}\text { Increased risk of RCC after } \\
\text { prior neuroblastoma, with or } \\
\text { without exposure to } \\
\text { chemotherapy }\end{array}$ & $\begin{array}{l}\text { Oncocytic appearance, appearance similar to MiT } \\
\text { family TRCC; positive for PAX8 }\end{array}$ & $\begin{array}{l}\text { A subgroup } \\
\text { demonstrates } \\
\text { TFE3/TFEB } \\
\text { rearrangement }\end{array}$ \\
\hline $\begin{array}{l}\text { Thyroid-like } \\
\text { follicular RCC }\end{array}$ & $\begin{array}{l}\text { Extremely rare, broad age } \\
\text { range, slight female } \\
\text { predominance, indolent }\end{array}$ & $\begin{array}{l}\text { Thyroid parenchyma-like appearance with follicles } \\
\text { and colloid; positive for PAX8 and negative for } \\
\text { PAX2, TTF-1, and thyroglobulin }\end{array}$ & NA \\
\hline $\begin{array}{l}\text { ALK rearrangement- } \\
\text { associated } R C C\end{array}$ & $\begin{array}{l}0.4 \% \text { of adult RCCs, sickle } \\
\text { cell trait }\end{array}$ & $\begin{array}{l}\text { With sickle cell trait: renal medullary carcinoma- } \\
\text { like morphology; without sickle cell trait: papillary, } \\
\text { solid, and tubular patterns with prominent } \\
\text { nucleoli and eosinophilic cytoplasm with } \\
\text { psammoma bodies; positive for ALK and TFE3 }\end{array}$ & $\begin{array}{l}A L K \text { rearrangement; } \\
\text { reported fusion partners } \\
\text { are } V C L, T P M 3, E M L 4, \\
S T R N \text {, and HOOK1 }\end{array}$ \\
\hline
\end{tabular}

CCPRCC, clear cell papillary RCC; CCRCC, clear cell RCC; MiT, microphthalmia transcription factor; NA, not available; RCC, renal cell carcinoma; TRCC, translocation RCC; WHO, World Health Organization.

\subsection{Oncocytic RCC Occurring after Neuroblastoma}

There is an increased risk of RCC in a patient with neuroblastoma. Oncocytic RCC occurring after neuroblastoma can develop in patients who have a history of neuroblastoma, with or without exposure to chemotherapy [1,76-78]. However, renal neoplasms occurring in patients with prior neuroblastoma are thought to represent a heterogeneous group of RCCs, not a single entity [76]. Oncocytic RCC occurring after neuroblastoma demonstrates diverse morphologic features, including an oncocytic appearance that is similar to the typical morphology of MiT family TRCCs. Immunohistochemically, this tumor is positive for PAX8 [76]. Genetically, a subgroup of this tumor demonstrates a TFE3/TFEB rearrangement [76]. Further studies are required to clarify whether this tumor entity is distinct, with unique histopathological and molecular characteristics.

\subsection{Thyroid-Like Follicular RCC}

Thyroid-like follicular RCC, an extremely rare RCC, resembles thyroid parenchyma with an abundant colloid-like material and is clinically indolent, with rare examples of metastases. The age range is broad, and patients are predominantly female [1,28,79-81]. Macroscopically, the tumor typically displays a tan-brown appearance. Microscopically, the tumor resembles thyroid parenchyma with follicles and colloid. Immunohistochemically, the tumor is typically positive for PAX8 and negative for PAX2, TTF-1, and thyroglobulin; TTF-1 or thyroglobulin is required to rule out metastases from thyroid cancer. Little is known about the molecular characteristics of thyroid-like follicular RCC.

\subsection{ALK Rearrangement-Associated RCC}

$A L K$ rearrangement-associated RCC occurs in children and adults, with or without sickle cell trait, comprising approximately $0.4 \%$ of all adult RCCs [82-89]. In young patients with sickle cell trait, the tumor demonstrates morphological features similar to those of renal medullary carcinoma [86,87]. In patients without sickle cell trait, the tumor morphologically demonstrates papillary, solid, and tubular patterns with prominent nucleoli and eosinophilic cytoplasm, including rhabdoid or signet-ring cell features with psammoma bodies [82,83]. The tumor displays cytoplasmic ALK and nuclear TFE3 immunostaining [82,83,88]. Because ALK rearrangement-associated RCC can be immunohistochemically positive for TFE3, such a result should be cautiously interpreted in a differential diagnosis with Xp11 TRCC. Genetically, reported partners of ALK are VCL, TPM3, EML4, STRN, and HOOK1 $[82,83,86,87,89]$. Because ALK rearrangement-associated RCCs are 
potentially responsive to ALK inhibitors [90-95], reasonable efforts should be made to identify ALK rearrangement-associated RCCs.

\subsection{RCC with (Angio)Leiomyomatous Stroma}

RCC with (angio)leiomyomatous stroma has been recently identified as an RCC subtype, but was historically categorized as either a CCRCC or CCPRCC $[1,96-98]$. This tumor occurs sporadically and can be associated with tuberous sclerosis [99]. Microscopically, the tumor is typically composed of neoplastic glandular structures lined by cells with mixed clear, pale, and eosinophilic cytoplasm, forming occasional papillary structures. The stroma of this tumor resembles smooth muscle and often extends away from the epithelial component [98]. Immunohistochemically, the epithelial component is typically positive for CAIX, CD10, CK7, 34betaE12, and PAX8, and negative for AMACR and HMB45. The stromal component is typically positive for SMA and caldesmon [98]. Genetically, the tumor does not have a $3 p$ deletion or trisomy 7 or 17 [98]. Recent evidence suggests an association of this tumor with TCEB1 mutations [100].

\section{Conclusions and Future Directions}

This review introduces and briefly summarizes the molecular pathological epidemiology of both new and current subtypes of renal cell tumors, as well as emerging/provisional RCCs, in the new 2016 WHO classification. The increased understanding of morphological, immunohistochemical, molecular, and epidemiological features of renal cell tumors enables us to categorize renal neoplasms into subtypes/entities with distinct characteristics. In the near future, the WHO classification will need to be further revised to allow for reliable, clinically meaningful diagnoses of these tumors. For that purpose, a more detailed and comprehensive understanding of their molecular pathological epidemiologic features is required.

Acknowledgments: The author thanks Tomoyo Kakita for her technical assistance and Yuki Takano and Chikako Yoshida for their secretarial expertise. This study was supported by JSPS KAKENHI Grant Number JP16K08679; and the Ministry of the Environment, Japan.

\section{Abbreviations}

$\begin{array}{ll}\text { 2SC } & \text { S-(2-succino)-cysteine } \\ \text { ACD } & \text { acquired cystic disease } \\ \text { CCPRCC } & \text { clear cell papillary RCC } \\ \text { CCRCC } & \text { clear cell RCC } \\ \text { Chr } & \text { chromosome } \\ \text { ChRCC } & \text { chromophobe RCC } \\ \text { FFPE } & \text { formalin-fixed paraffin-embedded } \\ \text { FH } & \text { fumarate hydratase } \\ \text { HIF } & \text { hypoxia-inducible factor } \\ \text { HLRCC } & \text { hereditary leiomyomatosis and RCC } \\ \text { ICD } & \text { imbalanced chromosome duplication } \\ \text { ISUP } & \text { International Society of Urological Pathology } \\ \text { PRCC } & \text { papillary RCC } \\ \text { RCC } & \text { renal cell carcinoma } \\ \text { SDH } & \text { succinate dehydrogenase } \\ \text { TCGA } & \text { The Cancer Genome Atlas } \\ \text { TRCC } & \text { translocation RCC } \\ \text { VHL } & \text { von Hippel Lindau } \\ \text { WHO } & \text { World Health Organization }\end{array}$




\section{References}

1. Moch, H.; Humphrey, P.A.; Ulbright, T.M.; Reuter, V.E. WHO Classification of Tumours of the Urinary System and Male Genital Organs, 4th ed.; IARC Press: Lyon, France, 2016.

2. The Cancer Genome Atlas Research Network. Comprehensive molecular characterization of clear cell renal cell carcinoma. Nature 2013, 499, 43-49.

3. Linehan, W.M.; Spellman, P.T.; Ricketts, C.J.; Creighton, C.J.; Fei, S.S.; Davis, C.; Wheeler, D.A.; Murray, B.A.; Schmidt, L.; Vocke, C.D.; et al. Comprehensive molecular characterization of papillary renal-cell carcinoma. N. Engl. J. Med. 2016, 374, 135-145. [PubMed]

4. $\quad$ Davis, C.F.; Ricketts, C.J.; Wang, M.; Yang, L.; Cherniack, A.D.; Shen, H.; Buhay, C.; Kang, H.; Kim, S.C.; Fahey, C.C.; et al. The somatic genomic landscape of chromophobe renal cell carcinoma. Cancer Cell 2014, 26, 319-330. [CrossRef] [PubMed]

5. Durinck, S.; Stawiski, E.W.; Pavia-Jimenez, A.; Modrusan, Z.; Kapur, P.; Jaiswal, B.S.; Zhang, N.; Toffessi-Tcheuyap, V.; Nguyen, T.T.; Pahuja, K.B.; et al. Spectrum of diverse genomic alterations define non-clear cell renal carcinoma subtypes. Nat. Genet. 2015, 47, 13-21. [CrossRef] [PubMed]

6. Hakimi, A.A.; Reznik, E.; Lee, C.H.; Creighton, C.J.; Brannon, A.R.; Luna, A.; Aksoy, B.A.; Liu, E.M.; Shen, R.; Lee, W.; et al. An Integrated metabolic atlas of clear cell renal cell carcinoma. Cancer Cell 2016, 29, $104-116$. [CrossRef] [PubMed]

7. Gotoh, M.; Ichikawa, H.; Arai, E.; Chiku, S.; Sakamoto, H.; Fujimoto, H.; Hiramoto, M.; Nammo, T.; Yasuda, K.; Yoshida, T.; et al. Comprehensive exploration of novel chimeric transcripts in clear cell renal cell carcinomas using whole transcriptome analysis. Genes Chromosomes Cancer 2014, 53, 1018-1032. [CrossRef] [PubMed]

8. Malouf, G.G.; Zhang, J.; Yuan, Y.; Comperat, E.; Roupret, M.; Cussenot, O.; Chen, Y.; Thompson, E.J.; Tannir, N.M.; Weinstein, J.N.; et al. Characterization of long non-coding RNA transcriptome in clear-cell renal cell carcinoma by next-generation deep sequencing. Mol. Oncol. 2015, 9, 32-43. [CrossRef] [PubMed]

9. Gowrishankar, B.; Przybycin, C.G.; Ma, C.; Nandula, S.V.; Rini, B.; Campbell, S.; Klein, E.; Chaganti, R.S.; Magi-Galluzzi, C.; Houldsworth, J. A genomic algorithm for the molecular classification of common renal cortical neoplasms: Development and validation. J. Urol. 2015, 193, 1479-1485. [CrossRef] [PubMed]

10. Christinat, Y.; Krek, W. Integrated genomic analysis identifies subclasses and prognosis signatures of kidney cancer. Oncotarget 2015, 6, 10521-10531. [CrossRef] [PubMed]

11. Eckel-Passow, J.E.; Igel, D.A.; Serie, D.J.; Joseph, R.W.; Ho, T.H.; Cheville, J.C.; Parker, A.S. Assessing the clinical use of clear cell renal cell carcinoma molecular subtypes identified by RNA expression analysis. Urol. Oncol. 2015, 33, 17-23. [CrossRef] [PubMed]

12. Rathmell, K.W.; Chen, F.; Creighton, C.J. Genomics of chromophobe renal cell carcinoma: Implications from a rare tumor for pan-cancer studies. Oncoscience 2015, 2, 81-90. [CrossRef] [PubMed]

13. Malouf, G.G.; Ali, S.M.; Wang, K.; Balasubramanian, S.; Ross, J.S.; Miller, V.A.; Stephens, P.J.; Khayat, D.; Pal, S.K.; Su, X.; et al. Genomic characterization of renal cell carcinoma with sarcomatoid dedifferentiation pinpoints recurrent genomic alterations. Eur. Urol. 2016, 70, 348-357. [CrossRef] [PubMed]

14. Chen, Y.B.; Xu, J.; Skanderup, A.J.; Dong, Y.; Brannon, A.R.; Wang, L.; Won, H.H.; Wang, P.I.; Nanjangud, G.J.; Jungbluth, A.A.; et al. Molecular analysis of aggressive renal cell carcinoma with unclassified histology reveals distinct subsets. Nat. Commun. 2016, 7, 13131. [CrossRef] [PubMed]

15. De Velasco, G.; Culhane, A.C.; Fay, A.P.; Hakimi, A.A.; Voss, M.H.; Tannir, N.M.; Tamboli, P.; Appleman, L.J.; Bellmunt, J.; Kimryn Rathmell, W.; et al. Molecular subtypes improve prognostic value of international metastatic renal cell carcinoma database consortium prognostic model. Oncologist 2017, 22, $286-292$. [CrossRef] [PubMed]

16. Seles, M.; Hutterer, G.C.; Kiesslich, T.; Pummer, K.; Berindan-Neagoe, I.; Perakis, S.; Schwarzenbacher, D.; Stotz, M.; Gerger, A.; Pichler, M. Current insights into long non-coding RNAs in renal cell carcinoma. Int. J. Mol. Sci. 2016, 17, 573. [CrossRef] [PubMed]

17. Kedzierska, H.; Poplawski, P.; Hoser, G.; Rybicka, B.; Rodzik, K.; Sokol, E.; Boguslawska, J.; Tanski, Z.; Fogtman, A.; Koblowska, M.; et al. Decreased Expression of SRSF2 Splicing Factor Inhibits Apoptotic Pathways in Renal Cancer. Int. J. Mol. Sci. 2016, 17, 1598. [CrossRef] [PubMed] 
18. Kim, H.; Komiyama, T.; Inomoto, C.; Kamiguchi, H.; Kajiwara, H.; Kobayashi, H.; Nakamura, N.; Terachi, T. Mutations in the mitochondrial nd1 gene are associated with postoperative prognosis of localized renal cell carcinoma. Int. J. Mol. Sci. 2016, 17, 2049. [CrossRef] [PubMed]

19. Xu, Q.; Krause, M.; Samoylenko, A.; Vainio, S. Wnt Signaling in Renal Cell Carcinoma. Cancers 2016, 8, 57. [CrossRef] [PubMed]

20. Miyata, Y.; Asai, A.; Mitsunari, K.; Matsuo, T.; Ohba, K.; Mochizuki, Y.; Sakai, H. Met in urological cancers. Cancers 2014, 6, 2387-2403. [CrossRef] [PubMed]

21. Petrozza, V.; Carbone, A.; Bellissimo, T.; Porta, N.; Palleschi, G.; Pastore, A.L.; Di Carlo, A.; Della Rocca, C.; Fazi, F. Oncogenic MicroRNAs Characterization in Clear Cell Renal Cell Carcinoma. Int. J. Mol. Sci. 2015, 16, 29219-29225. [CrossRef] [PubMed]

22. Mehdi, A.; Riazalhosseini, Y. Epigenome Aberrations: Emerging driving factors of the clear cell renal cell carcinoma. Int. J. Mol. Sci. 2017, 18, 1774. [CrossRef] [PubMed]

23. Hsieh, J.J.; Purdue, M.P.; Signoretti, S.; Swanton, C.; Albiges, L.; Schmidinger, M.; Heng, D.Y.; Larkin, J.; Ficarra, V. Renal cell carcinoma. Nat. Rev. Dis. Primers 2017, 3, 17009. [CrossRef] [PubMed]

24. Casuscelli, J.; Weinhold, N.; Gundem, G.; Wang, L.; Zabor, E.C.; Drill, E.; Wang, P.I.; Nanjangud, G.J.; Redzematovic, A.; Nargund, A.M.; et al. Genomic landscape and evolution of metastatic chromophobe renal cell carcinoma. JCI Insight 2017, 2, 92688. [CrossRef] [PubMed]

25. Hsieh, J.J.; Chen, D.; Wang, P.I.; Marker, M.; Redzematovic, A.; Chen, Y.B.; Selcuklu, S.D.; Weinhold, N.; Bouvier, N.; Huberman, K.H.; et al. Genomic biomarkers of a randomized trial comparing first-line everolimus and sunitinib in patients with metastatic renal cell carcinoma. Eur. Urol. 2017, 71, 405-414. [CrossRef] [PubMed]

26. Xu, J.; Pham, C.G.; Albanese, S.K.; Dong, Y.; Oyama, T.; Lee, C.H.; Rodrik-Outmezguine, V.; Yao, Z.; Han, S.; Chen, D.; et al. Mechanistically distinct cancer-associated mTOR activation clusters predict sensitivity to rapamycin. J. Clin. Investig. 2016, 126, 3526-3540. [CrossRef] [PubMed]

27. Joshi, S.; Tolkunov, D.; Aviv, H.; Hakimi, A.A.; Yao, M.; Hsieh, J.J.; Ganesan, S.; Chan, C.S.; White, E. The genomic landscape of renal oncocytoma identifies a metabolic barrier to tumorigenesis. Cell Rep. 2015, 13, 1895-1908. [CrossRef] [PubMed]

28. Srigley, J.R.; Delahunt, B.; Eble, J.N.; Egevad, L.; Epstein, J.I.; Grignon, D.; Hes, O.; Moch, H.; Montironi, R.; Tickoo, S.K.; et al. The International Society of Urological Pathology (ISUP) Vancouver Classification of Renal Neoplasia. Am. J. Surg. Pathol. 2013, 37, 1469-1489. [CrossRef] [PubMed]

29. Shen, C.; Kaelin, W.G., Jr. The VHL/HIF axis in clear cell renal carcinoma. Semin. Cancer Biol. 2013, 23, 18-25. [CrossRef] [PubMed]

30. Haake, S.M.; Rathmell, W.K. Renal cancer subtypes: Should we be lumping or splitting for therapeutic decision making? Cancer 2017, 123, 200-209. [CrossRef] [PubMed]

31. Giles, R.H.; Choueiri, T.K.; Heng, D.Y.; Albiges, L.; Hsieh, J.J.; Linehan, W.M.; Pal, S.; Maskens, D.; Paseman, B.; Jonasch, E.; et al. Recommendations for the management of rare kidney cancers. Eur. Urol. 2017, in press. [CrossRef] [PubMed]

32. Eble, J.N.; Sauter, G.; Epstein, J.I.; Sesterhenn, I.A. World Health Organization Classification of Tumours. In Pathology and Genetics of Tumours of the Urinary System and Male Genital Organs, 3rd ed.; IARC Press: Lyon, France, 2004.

33. Williamson, S.R.; Halat, S.; Eble, J.N.; Grignon, D.J.; Lopez-Beltran, A.; Montironi, R.; Tan, P.H.; Wang, M.; Zhang, S.; Maclennan, G.T.; et al. Multilocular cystic renal cell carcinoma: Similarities and differences in immunoprofile compared with clear cell renal cell carcinoma. Am. J. Surg. Pathol. 2012, 36, 1425-1433. [CrossRef] [PubMed]

34. Halat, S.; Eble, J.N.; Grignon, D.J.; Lopez-Beltran, A.; Montironi, R.; Tan, P.H.; Wang, M.; Zhang, S.; MacLennan, G.T.; Cheng, L. Multilocular cystic renal cell carcinoma is a subtype of clear cell renal cell carcinoma. Mod. Pathol. 2010, 23, 931-936. [CrossRef] [PubMed]

35. Von Teichman, A.; Comperat, E.; Behnke, S.; Storz, M.; Moch, H.; Schraml, P. VHL mutations and dysregulation of pVHL- and PTEN-controlled pathways in multilocular cystic renal cell carcinoma. Mod. Pathol. 2011, 24, 571-578. [CrossRef] [PubMed]

36. Inamura, K. Translocation Renal Cell Carcinoma: An update on clinicopathological and molecular features. Cancers 2017, 9, 111. [CrossRef] [PubMed] 
37. Kmetec, A.; Jeruc, J. Xp 11.2 translocation renal carcinoma in young adults; recently classified distinct subtype. Radiol. Oncol. 2014, 48, 197-202. [CrossRef] [PubMed]

38. Sukov, W.R.; Hodge, J.C.; Lohse, C.M.; Leibovich, B.C.; Thompson, R.H.; Pearce, K.E.; Wiktor, A.E.; Cheville, J.C. TFE3 rearrangements in adult renal cell carcinoma: Clinical and pathologic features with outcome in a large series of consecutively treated patients. Am. J. Surg. Pathol. 2012, 36, 663-670. [CrossRef] [PubMed]

39. Smith, N.E.; Illei, P.B.; Allaf, M.; Gonzalez, N.; Morris, K.; Hicks, J.; Demarzo, A.; Reuter, V.E.; Amin, M.B.; Epstein, J.I.; et al. t(6;11) renal cell carcinoma (RCC): Expanded immunohistochemical profile emphasizing novel RCC markers and report of 10 new genetically confirmed cases. Am. J. Surg. Pathol. 2014, 38, 604-614. [CrossRef] [PubMed]

40. Argani, P.; Antonescu, C.R.; Illei, P.B.; Lui, M.Y.; Timmons, C.F.; Newbury, R.; Reuter, V.E.; Garvin, A.J.; Perez-Atayde, A.R.; Fletcher, J.A.; et al. Primary renal neoplasms with the ASPL-TFE3 gene fusion of alveolar soft part sarcoma: A distinctive tumor entity previously included among renal cell carcinomas of children and adolescents. Am. J. Pathol. 2001, 159, 179-192. [CrossRef]

41. Argani, P.; Antonescu, C.R.; Couturier, J.; Fournet, J.C.; Sciot, R.; Debiec-Rychter, M.; Hutchinson, B.; Reuter, V.E.; Boccon-Gibod, L.; Timmons, C.; et al. PRCC-TFE3 renal carcinomas: Morphologic, immunohistochemical, ultrastructural, and molecular analysis of an entity associated with the t(X;1)(p11.2;q21). Am. J. Surg. Pathol. 2002, 26, 1553-1566. [CrossRef] [PubMed]

42. Argani, P.; Lae, M.; Hutchinson, B.; Reuter, V.E.; Collins, M.H.; Perentesis, J.; Tomaszewski, J.E.; Brooks, J.S.; Acs, G.; Bridge, J.A.; et al. Renal carcinomas with the $\mathrm{t}(6 ; 11)(\mathrm{p} 21 ; \mathrm{q} 12)$ : Clinicopathologic features and demonstration of the specific alpha-TFEB gene fusion by immunohistochemistry, RT-PCR, and DNA PCR. Am. J. Surg. Pathol. 2005, 29, 230-240. [CrossRef] [PubMed]

43. Argani, P.; Yonescu, R.; Morsberger, L.; Morris, K.; Netto, G.J.; Smith, N.; Gonzalez, N.; Illei, P.B.; Ladanyi, M.; Griffin, C.A. Molecular confirmation of $\mathrm{t}(6 ; 11)(\mathrm{p} 21 ; \mathrm{q} 12)$ renal cell carcinoma in archival paraffin-embedded material using a break-apart TFEB FISH assay expands its clinicopathologic spectrum. Am. J. Surg. Pathol. 2012, 36, 1516-1526. [CrossRef] [PubMed]

44. Argani, P.; Olgac, S.; Tickoo, S.K.; Goldfischer, M.; Moch, H.; Chan, D.Y.; Eble, J.N.; Bonsib, S.M.; Jimeno, M.; Lloreta, J.; et al. Xp11 translocation renal cell carcinoma in adults: Expanded clinical, pathologic, and genetic spectrum. Am. J. Surg. Pathol. 2007, 31, 1149-1160. [CrossRef] [PubMed]

45. Inamura, K.; Fujiwara, M.; Togashi, Y.; Nomura, K.; Mukai, H.; Fujii, Y.; Yamamoto, S.; Yonese, J.; Fukui, I.; Ishikawa, Y. Diverse fusion patterns and heterogeneous clinicopathologic features of renal cell carcinoma with $\mathrm{t}(6 ; 11)$ translocation. Am. J. Surg. Pathol. 2012, 36, 35-42. [CrossRef] [PubMed]

46. Argani, P.; Lal, P.; Hutchinson, B.; Lui, M.Y.; Reuter, V.E.; Ladanyi, M. Aberrant nuclear immunoreactivity for TFE3 in neoplasms with TFE3 gene fusions: A sensitive and specific immunohistochemical assay. Am. J. Surg. Pathol. 2003, 27, 750-761. [CrossRef] [PubMed]

47. Rao, Q.; Williamson, S.R.; Zhang, S.; Eble, J.N.; Grignon, D.J.; Wang, M.; Zhou, X.J.; Huang, W.; Tan, P.H.; Maclennan, G.T.; et al. TFE3 break-apart FISH has a higher sensitivity for Xp11.2 translocation-associated renal cell carcinoma compared with TFE3 or cathepsin $\mathrm{K}$ immunohistochemical staining alone: Expanding the morphologic spectrum. Am. J. Surg. Pathol. 2013, 37, 804-815. [CrossRef] [PubMed]

48. Green, W.M.; Yonescu, R.; Morsberger, L.; Morris, K.; Netto, G.J.; Epstein, J.I.; Illei, P.B.; Allaf, M.; Ladanyi, M.; Griffin, C.A.; et al. Utilization of a TFE3 break-apart FISH assay in a renal tumor consultation service. Am. J. Surg. Pathol. 2013, 37, 1150-1163. [CrossRef] [PubMed]

49. Lee, H.J.; Shin, D.H.; Noh, G.Y.; Kim, Y.K.; Kim, A.; Shin, N.; Lee, J.H.; Choi, K.U.; Kim, J.Y.; Lee, C.H.; et al. Combination of immunohistochemistry, FISH and RT-PCR shows high incidence of Xp11 translocation RCC: Comparison of three different diagnostic methods. Oncotarget 2017, 8, 30756-30765. [CrossRef] [PubMed]

50. Argani, P.; Reuter, V.E.; Zhang, L.; Sung, Y.S.; Ning, Y.; Epstein, J.I.; Netto, G.J.; Antonescu, C.R. TFEB-amplified renal cell carcinomas: An aggressive molecular subset demonstrating variable melanocytic marker expression and morphologic heterogeneity. Am. J. Surg. Pathol. 2016, 40, 1484-1495. [CrossRef] [PubMed]

51. Azoulay, S.; Vieillefond, A.; Paraf, F.; Pasquier, D.; Cussenot, O.; Callard, P.; Sibony, M. Tubulocystic carcinoma of the kidney: A new entity among renal tumors. Virchows Arch. 2007, 451, 905-909. [CrossRef] [PubMed] 
52. Yang, X.J.; Zhou, M.; Hes, O.; Shen, S.; Li, R.; Lopez, J.; Shah, R.B.; Yang, Y.; Chuang, S.T.; Lin, F.; et al. Tubulocystic carcinoma of the kidney: Clinicopathologic and molecular characterization. Am. J. Surg. Pathol. 2008, 32, 177-187. [CrossRef] [PubMed]

53. Amin, M.B.; MacLennan, G.T.; Gupta, R.; Grignon, D.; Paraf, F.; Vieillefond, A.; Paner, G.P.; Stovsky, M.; Young, A.N.; Srigley, J.R.; et al. Tubulocystic carcinoma of the kidney: Clinicopathologic analysis of 31 cases of a distinctive rare subtype of renal cell carcinoma. Am. J. Surg. Pathol. 2009, 33, 384-392. [CrossRef] [PubMed]

54. Zhou, M.; Yang, X.J.; Lopez, J.I.; Shah, R.B.; Hes, O.; Shen, S.S.; Li, R.; Yang, Y.; Lin, F.; Elson, P.; et al. Renal tubulocystic carcinoma is closely related to papillary renal cell carcinoma: Implications for pathologic classification. Am. J. Surg. Pathol. 2009, 33, 1840-1849. [CrossRef] [PubMed]

55. Al-Hussain, T.O.; Cheng, L.; Zhang, S.; Epstein, J.I. Tubulocystic carcinoma of the kidney with poorly differentiated foci: A series of 3 cases with fluorescence in situ hybridization analysis. Hum. Pathol. 2013, 44, 1406-1411. [CrossRef] [PubMed]

56. Osunkoya, A.O.; Young, A.N.; Wang, W.; Netto, G.J.; Epstein, J.I. Comparison of gene expression profiles in tubulocystic carcinoma and collecting duct carcinoma of the kidney. Am. J. Surg. Pathol. 2009, 33, 1103-1106. [CrossRef] [PubMed]

57. Smith, S.C.; Trpkov, K.; Chen, Y.B.; Mehra, R.; Sirohi, D.; Ohe, C.; Cani, A.K.; Hovelson, D.H.; Omata, K.; McHugh, J.B.; et al. Tubulocystic carcinoma of the kidney with poorly differentiated foci: A frequent morphologic pattern of fumarate hydratase-deficient renal cell carcinoma. Am. J. Surg. Pathol. 2016, 40, 1457-1472. [CrossRef] [PubMed]

58. Foshat, M.; Eyzaguirre, E. Acquired cystic disease-associated renal cell carcinoma: Review of pathogenesis, morphology, ancillary tests, and clinical features. Arch. Pathol. Lab. Med. 2017, 141, 600-606. [CrossRef] [PubMed]

59. Tickoo, S.K.; dePeralta-Venturina, M.N.; Harik, L.R.; Worcester, H.D.; Salama, M.E.; Young, A.N.; Moch, H.; Amin, M.B. Spectrum of epithelial neoplasms in end-stage renal disease: An experience from 66 tumor-bearing kidneys with emphasis on histologic patterns distinct from those in sporadic adult renal neoplasia. Am. J. Surg. Pathol. 2006, 30, 141-153. [CrossRef] [PubMed]

60. Cossu-Rocca, P.; Eble, J.N.; Zhang, S.; Martignoni, G.; Brunelli, M.; Cheng, L. Acquired cystic disease-associated renal tumors: An immunohistochemical and fluorescence in situ hybridization study. Mod. Pathol. 2006, 19, 780-787. [CrossRef] [PubMed]

61. Zhou, H.; Zheng, S.; Truong, L.D.; Ro, J.Y.; Ayala, A.G.; Shen, S.S. Clear cell papillary renal cell carcinoma is the fourth most common histologic type of renal cell carcinoma in 290 consecutive nephrectomies for renal cell carcinoma. Hum. Pathol. 2014, 45, 59-64. [CrossRef] [PubMed]

62. Williamson, S.R.; Eble, J.N.; Cheng, L.; Grignon, D.J. Clear cell papillary renal cell carcinoma: Differential diagnosis and extended immunohistochemical profile. Mod. Pathol. 2013, 26, 697-708. [CrossRef] [PubMed]

63. Aydin, H.; Chen, L.; Cheng, L.; Vaziri, S.; He, H.; Ganapathi, R.; Delahunt, B.; Magi-Galluzzi, C.; Zhou, M. Clear cell tubulopapillary renal cell carcinoma: A study of 36 distinctive low-grade epithelial tumors of the kidney. Am. J. Surg. Pathol. 2010, 34, 1608-1621. [CrossRef] [PubMed]

64. Diolombi, M.L.; Cheng, L.; Argani, P.; Epstein, J.I. Do clear cell papillary renal cell carcinomas have malignant potential? Am. J. Surg. Pathol. 2015, 39, 1621-1634. [CrossRef] [PubMed]

65. Gobbo, S.; Eble, J.N.; Grignon, D.J.; Martignoni, G.; MacLennan, G.T.; Shah, R.B.; Zhang, S.; Brunelli, M.; Cheng, L. Clear cell papillary renal cell carcinoma: A distinct histopathologic and molecular genetic entity. Am. J. Surg. Pathol. 2008, 32, 1239-1245. [CrossRef] [PubMed]

66. Adam, J.; Couturier, J.; Molinie, V.; Vieillefond, A.; Sibony, M. Clear-cell papillary renal cell carcinoma: 24 cases of a distinct low-grade renal tumour and a comparative genomic hybridization array study of seven cases. Histopathology 2011, 58, 1064-1071. [CrossRef] [PubMed]

67. Gill, A.J. Succinate dehydrogenase (SDH) and mitochondrial driven neoplasia. Pathology 2012, 44, $285-292$. [CrossRef] [PubMed]

68. Gill, A.J.; Hes, O.; Papathomas, T.; Sedivcova, M.; Tan, P.H.; Agaimy, A.; Andresen, P.A.; Kedziora, A.; Clarkson, A.; Toon, C.W.; et al. Succinate dehydrogenase (SDH)-deficient renal carcinoma: A morphologically distinct entity: A clinicopathologic series of 36 tumors from 27 patients. Am. J. Surg. Pathol. 2014, 38, 1588-1602. [CrossRef] [PubMed] 
69. Gill, A.J.; Pachter, N.S.; Clarkson, A.; Tucker, K.M.; Winship, I.M.; Benn, D.E.; Robinson, B.G.; Clifton-Bligh, R.J. Renal tumors and hereditary pheochromocytoma-paraganglioma syndrome type 4. N. Engl. J. Med. 2011, 364, 885-886. [CrossRef] [PubMed]

70. Williamson, S.R.; Eble, J.N.; Amin, M.B.; Gupta, N.S.; Smith, S.C.; Sholl, L.M.; Montironi, R.; Hirsch, M.S.; Hornick, J.L. Succinate dehydrogenase-deficient renal cell carcinoma: Detailed characterization of 11 tumors defining a unique subtype of renal cell carcinoma. Mod. Pathol. 2015, 28, 80-94. [CrossRef] [PubMed]

71. Lee, C.H.; Gundem, G.; Lee, W.; Chen, Y.B.; Cross, J.R.; Dong, Y.; Redzematovic, A.; Mano, R.; Wei, E.Y.; Cheng, E.H.; et al. Persistent severe hyperlactatemia and metabolic derangement in lethal SDHB-mutated metastatic kidney cancer: Clinical challenges and examples of extreme warburg effect. JCO Precis. Oncol. 2017, 1, 1-14. [CrossRef]

72. Grubb, R.L., 3rd; Franks, M.E.; Toro, J.; Middelton, L.; Choyke, L.; Fowler, S.; Torres-Cabala, C.; Glenn, G.M.; Choyke, P.; Merino, M.J.; et al. Hereditary leiomyomatosis and renal cell cancer: A syndrome associated with an aggressive form of inherited renal cancer. J. Urol. 2007, 177, 2074-2079; discussion 2079-2080. [CrossRef] [PubMed]

73. Merino, M.J.; Torres-Cabala, C.; Pinto, P.; Linehan, W.M. The morphologic spectrum of kidney tumors in hereditary leiomyomatosis and renal cell carcinoma (HLRCC) syndrome. Am. J. Surg. Pathol. 2007, 31, 1578-1585. [CrossRef] [PubMed]

74. Bardella, C.; El-Bahrawy, M.; Frizzell, N.; Adam, J.; Ternette, N.; Hatipoglu, E.; Howarth, K.; O'Flaherty, L.; Roberts, I.; Turner, G.; et al. Aberrant succination of proteins in fumarate hydratase-deficient mice and HLRCC patients is a robust biomarker of mutation status. J. Pathol. 2011, 225, 4-11. [CrossRef] [PubMed]

75. Trpkov, K.; Hes, O.; Agaimy, A.; Bonert, M.; Martinek, P.; Magi-Galluzzi, C.; Kristiansen, G.; Luders, C.; Nesi, G.; Comperat, E.; et al. Fumarate hydratase-deficient renal cell carcinoma is strongly correlated with fumarate hydratase mutation and hereditary leiomyomatosis and renal cell carcinoma syndrome. Am. J. Surg. Pathol. 2016, 40, 865-875. [CrossRef] [PubMed]

76. Falzarano, S.M.; McKenney, J.K.; Montironi, R.; Eble, J.N.; Osunkoya, A.O.; Guo, J.; Zhou, S.; Xiao, H.; Dhanasekaran, S.M.; Shukla, S.; et al. Renal cell carcinoma occurring in patients with prior neuroblastoma: A heterogenous group of neoplasms. Am. J. Surg. Pathol. 2016, 40, 989-997. [CrossRef] [PubMed]

77. Bassal, M.; Mertens, A.C.; Taylor, L.; Neglia, J.P.; Greffe, B.S.; Hammond, S.; Ronckers, C.M.; Friedman, D.L.; Stovall, M.; Yasui, Y.Y.; et al. Risk of selected subsequent carcinomas in survivors of childhood cancer: A report from the Childhood Cancer Survivor Study. J. Clin. Oncol. 2006, 24, 476-483. [CrossRef] [PubMed]

78. Medeiros, L.J.; Palmedo, G.; Krigman, H.R.; Kovacs, G.; Beckwith, J.B. Oncocytoid renal cell carcinoma after neuroblastoma: A report of four cases of a distinct clinicopathologic entity. Am. J. Surg. Pathol. 1999, 23, 772-780. [CrossRef] [PubMed]

79. Chougule, A.; Bal, A.; Das, A.; Nayak, B. Thyroid-like follicular renal cell carcinoma: An emerging morphological variant. Pathology 2014, 46, 657-660. [CrossRef] [PubMed]

80. Amin, M.B.; Gupta, R.; Ondrej, H.; McKenney, J.K.; Michal, M.; Young, A.N.; Paner, G.P.; Junker, K.; Epstein, J.I. Primary thyroid-like follicular carcinoma of the kidney: Report of 6 cases of a histologically distinctive adult renal epithelial neoplasm. Am. J. Surg. Pathol. 2009, 33, 393-400. [CrossRef] [PubMed]

81. Wang, H.; Yu, J.; Xu, Z.; Li, G. Clinicopathological study on thyroid follicular carcinoma-like renal tumor related to serious hypertension: Case report and review of the literature. Medicine 2017, 96, 6419. [CrossRef] [PubMed]

82. Kusano, H.; Togashi, Y.; Akiba, J.; Moriya, F.; Baba, K.; Matsuzaki, N.; Yuba, Y.; Shiraishi, Y.; Kanamaru, H.; Kuroda, N.; et al. Two cases of renal cell carcinoma harboring a novel strn-alk fusion gene. Am. J. Surg. Pathol. 2016, 40, 761-769. [CrossRef] [PubMed]

83. Sugawara, E.; Togashi, Y.; Kuroda, N.; Sakata, S.; Hatano, S.; Asaka, R.; Yuasa, T.; Yonese, J.; Kitagawa, M.; Mano, H.; et al. Identification of anaplastic lymphoma kinase fusions in renal cancer: Large-scale immunohistochemical screening by the intercalated antibody-enhanced polymer method. Cancer 2012, 118, 4427-4436. [CrossRef] [PubMed]

84. Smith, N.E.; Deyrup, A.T.; Marino-Enriquez, A.; Fletcher, J.A.; Bridge, J.A.; Illei, P.B.; Netto, G.J.; Argani, P. VCL-ALK renal cell carcinoma in children with sickle-cell trait: The eighth sickle-cell nephropathy? Am. J. Surg. Pathol. 2014, 38, 858-863. [CrossRef] [PubMed] 
85. Sukov, W.R.; Hodge, J.C.; Lohse, C.M.; Akre, M.K.; Leibovich, B.C.; Thompson, R.H.; Cheville, J.C. ALK alterations in adult renal cell carcinoma: Frequency, clinicopathologic features and outcome in a large series of consecutively treated patients. Mod. Pathol. 2012, 25, 1516-1525. [CrossRef] [PubMed]

86. Marino-Enriquez, A.; Ou, W.B.; Weldon, C.B.; Fletcher, J.A.; Perez-Atayde, A.R. ALK rearrangement in sickle cell trait-associated renal medullary carcinoma. Genes Chromosomes Cancer 2011, 50, 146-153. [CrossRef] [PubMed]

87. Debelenko, L.V.; Raimondi, S.C.; Daw, N.; Shivakumar, B.R.; Huang, D.; Nelson, M.; Bridge, J.A. Renal cell carcinoma with novel VCL-ALK fusion: New representative of ALK-associated tumor spectrum. Mod. Pathol. 2011, 24, 430-442. [CrossRef] [PubMed]

88. Cajaiba, M.M.; Jennings, L.J.; Rohan, S.M.; Perez-Atayde, A.R.; Marino-Enriquez, A.; Fletcher, J.A.; Geller, J.I.; Leuer, K.M.; Bridge, J.A.; Perlman, E.J. ALK-rearranged renal cell carcinomas in children. Genes Chromosomes Cancer 2016, 55, 442-451. [CrossRef] [PubMed]

89. Cajaiba, M.M.; Jennings, L.J.; George, D.; Perlman, E.J. Expanding the spectrum of ALK-rearranged renal cell carcinomas in children: Identification of a novel HOOK1-ALK fusion transcript. Genes Chromosomes Cancer 2016, 55, 814-817. [CrossRef] [PubMed]

90. Butrynski, J.E.; D’Adamo, D.R.; Hornick, J.L.; Dal Cin, P.; Antonescu, C.R.; Jhanwar, S.C.; Ladanyi, M.; Capelletti, M.; Rodig, S.J.; Ramaiya, N.; et al. Crizotinib in ALK-rearranged inflammatory myofibroblastic tumor. N. Engl. J. Med. 2010, 363, 1727-1733. [CrossRef] [PubMed]

91. Solomon, B.J.; Mok, T.; Kim, D.W.; Wu, Y.L.; Nakagawa, K.; Mekhail, T.; Felip, E.; Cappuzzo, F.; Paolini, J.; Usari, T.; et al. First-line crizotinib versus chemotherapy in ALK-positive lung cancer. N. Engl. J. Med. 2014, 371, 2167-2177. [CrossRef] [PubMed]

92. Li, J.; Sun, R.; Wu, Y.; Song, M.; Li, J.; Yang, Q.; Chen, X.; Bao, J.; Zhao, Q. L1198F mutation resensitizes Crizotinib to ALK by altering the conformation of inhibitor and atp binding sites. Int. J. Mol. Sci. 2017, 18, 482. [CrossRef] [PubMed]

93. Nenadic, I.; Staber, J.; Dreier, S.; Simons, G.; Schildgen, V.; Brockmann, M.; Schildgen, O. Cost saving opportunities in nsclc therapy by optimized diagnostics. Cancers 2017, 9, 88. [CrossRef] [PubMed]

94. Rothschild, S.I. Targeted therapies in non-small cell lung cancer-beyond EGFR and ALK. Cancers 2015, 7, 930-949. [CrossRef] [PubMed]

95. Peters, S.; Camidge, D.R.; Shaw, A.T.; Gadgeel, S.; Ahn, J.S.; Kim, D.W.; Ou, S.I.; Perol, M.; Dziadziuszko, R.; Rosell, R.; et al. Alectinib versus Crizotinib in untreated ALK-positive non-small-cell lung cancer. N. Engl. J. Med. 2017, 377, 829-838. [CrossRef] [PubMed]

96. Kuhn, E.; De Anda, J.; Manoni, S.; Netto, G.; Rosai, J. Renal cell carcinoma associated with prominent angioleiomyoma-like proliferation: Report of 5 cases and review of the literature. Am. J. Surg. Pathol. 2006, 30, 1372-1381. [CrossRef] [PubMed]

97. Shannon, B.A.; Cohen, R.J.; Segal, A.; Baker, E.G.; Murch, A.R. Clear cell renal cell carcinoma with smooth muscle stroma. Hum. Pathol. 2009, 40, 425-429. [CrossRef] [PubMed]

98. Williamson, S.R.; Cheng, L.; Eble, J.N.; True, L.D.; Gupta, N.S.; Wang, M.; Zhang, S.; Grignon, D.J. Renal cell carcinoma with angioleiomyoma-like stroma: Clinicopathological, immunohistochemical, and molecular features supporting classification as a distinct entity. Mod. Pathol. 2015, 28, 279-294. [CrossRef] [PubMed]

99. Guo, J.; Tretiakova, M.S.; Troxell, M.L.; Osunkoya, A.O.; Fadare, O.; Sangoi, A.R.; Shen, S.S.; Lopez-Beltran, A.; Mehra, R.; Heider, A.; et al. Tuberous sclerosis-associated renal cell carcinoma: A clinicopathologic study of 57 separate carcinomas in 18 patients. Am. J. Surg. Pathol. 2014, 38, 1457-1467. [CrossRef] [PubMed]

100. Hakimi, A.A.; Tickoo, S.K.; Jacobsen, A.; Sarungbam, J.; Sfakianos, J.P.; Sato, Y.; Morikawa, T.; Kume, H.; Fukayama, M.; Homma, Y.; et al. TCEB1-mutated renal cell carcinoma: A distinct genomic and morphological subtype. Mod. Pathol. 2015, 28, 845-853. [CrossRef] [PubMed]

(C) 2017 by the author. Licensee MDPI, Basel, Switzerland. This article is an open access article distributed under the terms and conditions of the Creative Commons Attribution (CC BY) license (http://creativecommons.org/licenses/by/4.0/). 